Dicle Tıp Dergisi / Dicle Medical Journal (2017) 44 (4) : 345-353

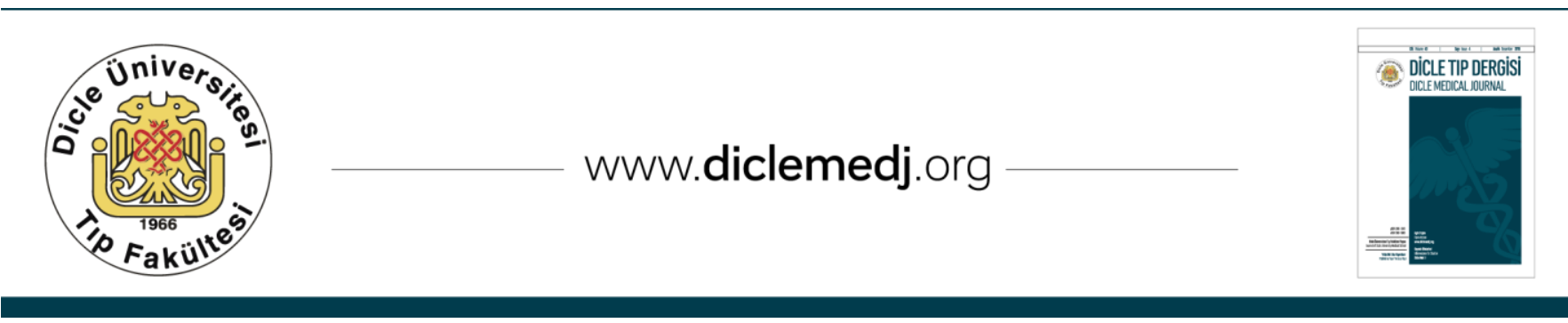

Özgün Araștırma / Original Article

\title{
Çocuk Acil Kliniğine Başvuran Adli Vakaların Değerlendirilmesi
}

\author{
Abdullah Yazar'1, Fatih Akın², Esra Türe², Dursun Odabaş ${ }^{4}$ \\ 1 Necmettin Erbakan Üniversitesi, Meram Tıp Fakültesi, Çocuk Sağlı̆ıı ve Hastalıkları Ana Bilim Dalı, Konya, Türkiye ORCID: 0000-0003-0733-3943 \\ 2 Necmettin Erbakan Üniversitesi, Meram Tıp Fakültesi, Çocuk Sağlı̆̆ı ve Hastalıkları Ana Bilim Dalı, Konya, Türkiye ORCID: 0000-0001-5725-3867 \\ 3 Necmettin Erbakan Üniversitesi, Meram Tıp Fakültesi, Çocuk Sağlı̆ıı ve Hastalıkları Ana Bilim Dal, Konya, Türkiye ORCID: 0000-0002-1015-1764 \\ 4 Necmettin Erbakan Üniversitesi, Meram Tıp Fakültesi, Çocuk Sağlığı ve Hastalıkları Ana Bilim Dalı, Konya, Türkiye ORCID: 0000-0002-2561-8275
}

GelişGeliş: 12.06.2017, Revizyon: 03.10.2017, Kabul Tarihi: 05.10.2017

\section{Özet}

Giriş: Çocukluk çağında meydana gelen adli olaylar tüm dünyada önlenebilir sağlık sorunlarının başında yer almaktadır. Bu çalışmada çocuk acil kliniğine başvuran, majör travma dışı adli vaka olarak değerlendirilen hastaların klinik ve demografik özelliklerinin ve tedavi yaklaşımlarının değerlendirilmesi amaçlanmıştır.

Yöntemler: Çocuk acil tıp kliniğimize Eylül 2015-Eylül 2016 tarihleri arasında başvuran 18 yaş altı 39756 hastadan, adli vaka olarak kabul edilen 683 hastanın dosyaları retrospektif olarak incelendi.

Bulgular: Adli olarak değerlendirilen 683 hastanın yaş aralığı 0-17 yıl arasında olup, tüm olguların yaş ortalaması $5,82 \pm 4,7$ yıl olarak bulundu. Erkek çocukların yaş ortalaması 6,37 $\pm 5,1$ yıl iken kız çocukların yaş ortalaması 5,36 $\pm 4,3$ yıl olarak tespit edildi. Çocuk acile gelen adli olguların 316'sının kız $(\% 46,3)$ ve 367'sinin erkek $(\% 53,7)$ olduğu tespit edildi. Adli olayların dağılımını incelediğimizde en fazla intoksikasyon vakalarının (n: $260, \% 38,1)$ görüldüğü tespit edildi. Olayların yaş gruplarına göre dağılımı incelendiğinde intoksikasyon vakalarının \%77,7'sinin 5 yaş altında, öz kıyım vakalarının \%76,9'unun 15 yaş üstünde, yabancı cisim yutma vakalarının \%62,3'ünün ve yabancı cisim aspirasyonu vakalarının \%90,5'inin 5 yaş altında, uyuşturucu kullanımı vakalarının \%89,5'inin en sık 15 yaş üstünde görüldüğü tespit edildi.

Sonuç: Tüm dünyada olduğu gibi ülkemizde de kazalar ve intoksikasyon vakaları, önlenebilir ölüm nedenlerinin başında gelmektedir. Bu tür olayların azaltılabilmesi için çocukların yaşadığı çevrelerde ve evde güvenlik için gerekli düzenlemeler yapılmalı, güvenliği sağlamak için gerektiğinde uygun güvenlik araçları kullanılmalıdır. Ayrıca eğitimciler ve sağlık profesyonelleri tarafından çocuklara ve ebeveynlere yaralanma korunma programları çerçevesinde düzenli eğitimler verilmelidir.

Anahtar kelimeler; Adli vaka, çocuk, zehirlenme

DOI: $10.5798 /$ dicletip.362395

Yazışma Adresi / Correspondence: Abdullah Yazar, Necmettin Erbakan Üniversitesi, Meram Tıp Fakültesi, Çocuk Sağlı̆̆ ve Hastalıkları ABD, 42080 Konya, Türkiye e-mail: drabdullahyazar@hotmail.com 


\title{
Evaluation of Forensic Cases Admitting to Pediatric Emergency Clinic
}

\begin{abstract}
Objectives: Childhood forensic events constitute most of the preventable health problems all over the world. This study aimed to evaluate the clinical and demographic characteristics and treatment procedures of non-traumatic pediatric forensic cases.

Methods: The files of 39756 patients aged under 18-years-old, who admitted to our pediatric emergency clinic between September 2015 and September 2016 were analysed retrospectively.

Results: The age range of 683 patients who were found to be forensic cases was $0-17$ years and the mean age was $5,82 \pm 4,7$ years. While mean age of boys was $6.37 \pm 5.1$ years, it was $5.36 \pm 4.3$ years for girls. It was determined that $316(46,3 \%)$ of the forensic cases admitting to pediatric emergency department were girls and 367 (53,7\%) were boys. The distribution of cases revealed that intoxication cases took the first place (n: 260, 38.1\%). When forensic events were evaluated according to age groups it was determined that $77 \%$ of intoxication cases were under 5 yearsold; $76.9 \%$ of suicide cases were over over 15 years-old; $62.3 \%$ of patients with foreign body swallowing were under 5-years-old; $62.3 \%$ of patients with foreign body aspiration were under 5-years-old; $89.5 \%$ of patients with narcotic drug usage were over 15-years-old.

Conclusion: Accidents and intoxication cases are the leading causes of preventable deaths in our country as in the whole world. In order to reduce such incidents, necessary arrangements must be made for safety at children's surroundings and home, and appropriate safety devices should be used when necessary to ensure this safety. Regular training should also be provided by trainers and health professionals on the basis of injury prevention programs for children and parents.
\end{abstract}

Keywords: Forensic cases, children, intoxication

\section{GİRIS}

Kişinin kendisinin veya başkasının kasıt, ihmal, tedbirsizlik ve dikkatsizliği sonucunda, sağlığının bozulmasına, yaralanmasına ya da ölümüne sebebiyet veren her olay adli vaka olarak tanımlanmaktadır. Hastane acil servislerine başvuran hastaların önemli bir kısmını adli vakalar oluşturmaktadır. Bir başkasının kasıtlı, tedbirsiz, dikkatsiz davranışı sonucu meydana gelen tüm yaralanmalar, kişinin bir başkası tarafından darp edilmesi, kesici, kesici-delici, ezici alet yaralanmaları, patlayıcı madde ve ateşli silah yaralanmaları, trafik kazaları, düşmeler, iş kazaları, zehirlenmeler, zehirlenme şüphesi olan vakalar, yasa dışı madde kullanımı, öz kıyım, yanıklar, elektrik ve yıldırım çarpmaları, vücuda herhangi bir yolla yabancl madde girmesi, her türlü şüpheli ölüm, insan hakları ihlali, işkence iddiaları, mekanik asfiksi olguları adli vaka niteliği taşımaktadır ${ }^{1}$.
Çocukluk çağında meydana gelen kazalar, tüm dünyada önlenebilir sağlık sorunlarının başında yer almaktadır ${ }^{2}$. Alınacak koruyucu önlemlerin ve tedavi yaklașımlarının adli vakaların sıklığını ve şiddetini azaltmadaki etkisi tartışmasızdır.

Çalışmamızda, Üniversitemiz Tıp Fakültesi Çocuk Acil Servisine başvuran adli olguların olay tipine göre dağılımının saptanması, yaş, cinsiyet, mevsim ve gerçekleşme zamanı gibi özelliklerine göre incelenmesi ve tedavi yaklaşımlarının amaçlanmıştır.

\section{YÖNTEMLER}

Üniversitesimiz Tıp Fakültesi Çocuk Acil Tıp Kliniği'ne Eylül 2015-Eylül 2016 tarihleri arasında başvuran, adli vaka olarak değerlendirilen 18 yaş altı hastaların adli raporlarl, hastane otomasyon sistemine girilen kayıtlar ve yatış dosyaları etik kurul onayı 
alındıktan sonra retrospektif olarak incelendi. Adli vaka olarak değerlendirilen ve kayıtlarına eksiksiz ulaşılabilen olgular çalışmaya dahil edildi. Hastaların yaş ve cinsiyetleri, acil servise başvuru şekilleri, ne zaman başvuru yaptıkları, hastaneye varış süreleri, adli vakaya sebep olan olay, acil servisteki takip ve tedavi yöntemleri standart veri giriş formuna kayit edildi. Verilerinde eksiklik tespit edilen hastalar ve travma hastaları çalışma dışı bırakıldı. Olguların tanıları intoksikasyon, intoksikasyon şüphesi, öz kıyım, yabancı cisim yutma, yabancı cisim yutma şüphesi, yabancı cisim aspirasyonu, yabancl cisim aspirasyonu şüphesi, cinsel istismar, fiziksel istismar, karbonmonoksit zehirlenmesi, uyuşturucu kullanımı, alkol kullanımı ve diğer olarak gruplandırıldı. Olgu sonuçları acil serviste ayaktan tedavi, hastane yatışı, sevk, ölüm, kendi isteği ile terk ve izinsiz terk başlıkları altında incelendi.

Tablo 1. Olguların yaș ve cinsiyete göre dağılımı

\begin{tabular}{lcccccc}
\hline Yaş & \multicolumn{2}{c}{ Kuz } & \multicolumn{2}{c}{ Erkek } & \multicolumn{2}{c}{ Toplam } \\
\hline & $\mathbf{n}$ & $\mathbf{\%}$ & $\mathbf{n}$ & $\mathbf{\%}$ & $\mathbf{n}$ & $\mathbf{\%}$ \\
<5 yaş & 197 & 62,3 & 232 & 64,6 & 434 & 63,5 \\
$\mathbf{5 - 1 0}$ yaş & 41 & 13 & 78 & 21,3 & 119 & 17,4 \\
$\mathbf{1 1 - 1 4}$ yaş & 34 & 10,8 & 23 & 6,3 & 57 & 8,3 \\
>15 yaş & 44 & 13,9 & 29 & 7,9 & 73 & 10,7 \\
Toplam & 316 & 100 & 367 & 100 & 683 & 100 \\
\hline
\end{tabular}

Tablo 2. Adli vakaların cinsiyete göre dağılımı

\begin{tabular}{lcccccc}
\hline Olgu tipi & \multicolumn{1}{c}{ Kız } & \multicolumn{2}{c}{ Erkek } & \multicolumn{2}{c}{ Toplam } \\
\hline & $\mathbf{n}$ & $\mathbf{0}$ & $\mathbf{n}$ & $\mathbf{\%}$ & $\mathbf{n}$ & $\mathbf{\%}$ \\
İntoksikasyon & 102 & 32,3 & 158 & 43,1 & 260 & 38,1 \\
İntoksikasyon şüphesi & 7 & 2,2 & 15 & 4,1 & 22 & 3,2 \\
Öz kıyım & 33 & 10,4 & 6 & 1,6 & 39 & 5,7 \\
Yabancı cisim yutma & 63 & 19,9 & 67 & 18,3 & 130 & 19 \\
Yabancı cisim yutma şüphesi & 7 & 2,2 & 3 & 0,8 & 10 & 1,5 \\
Yabancı cisim aspirasyonu & 8 & 2,5 & 13 & 3,5 & 21 & 3,1 \\
Yabancı cisim aspirasyon şüphesi & 1 & 0,3 & 6 & 1,6 & 7 & 1 \\
Cinsel istismar & 2 & 0,6 & 2 & 0,5 & 4 & 0,6 \\
Fiziksel istismar & 1 & 0,3 & 1 & 0,3 & 2 & 0,3 \\
Uyuşturucu kullanımı & 2 & 0,6 & 17 & 4,6 & 19 & 2,8 \\
Alkol kullanımı & 0 & 0 & 1 & 0,3 & 1 & 0,1 \\
Karbon monoksit zehirlenmesi & 23 & 7,3 & 19 & 5,2 & 42 & 6,1 \\
Ölü duhul & 3 & 0,9 & 1 & 0,3 & 4 & 0,6 \\
Diğer & 64 & 20,3 & 57 & 15,5 & 121 & 17,7 \\
\hline
\end{tabular}




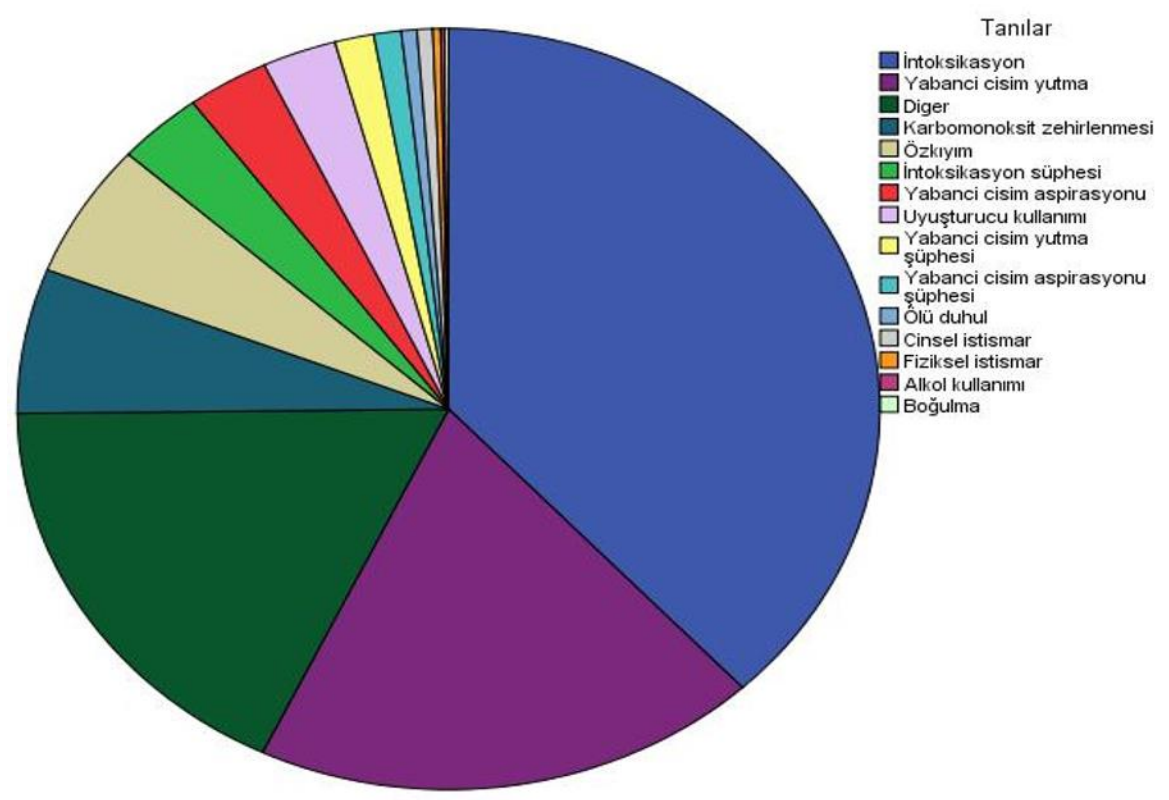

Şekil 1: Adli vakaların tanılara göre dağılımı

Çalışmanın istatistiksel analizi Statistical Package for the Social Sciences for Windows ver. 20.0 paket programı kullanılarak yapıldı. Verilerin dağılımı ve sıklığının analizlerinde tanımlayıcı analizler, frekans verilerde bağımsız iki grubun karşılaștırılmasında KiKare testleri ve frekans verilerde üç ve fazla grubun karşılaştırılmasında çok gözlü Ki-Kare testleri kullanıldı. Tüm istatistik analizlerde anlamlılık düzeyi $\mathrm{p}<0.05$ olarak kabul edildi.

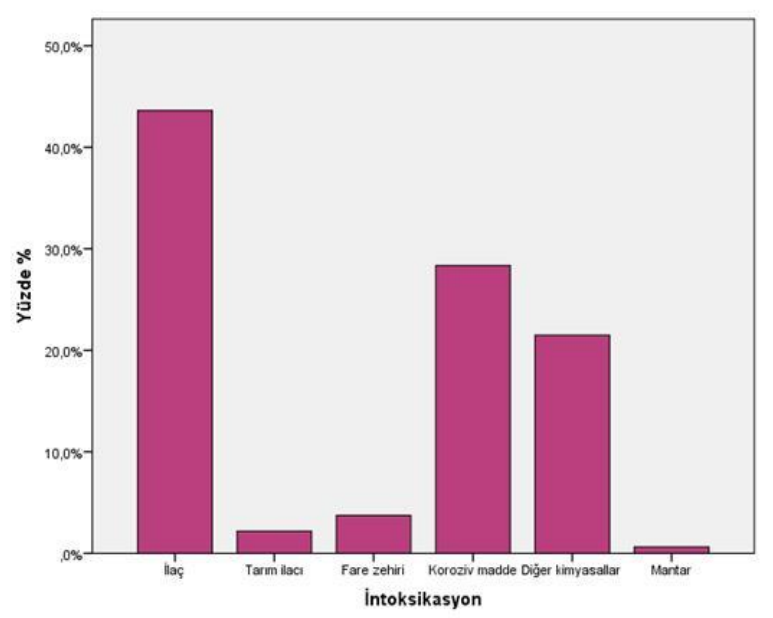

Şekil 2: İntoksikasyon olgularında kullanılan kimyasal madde yüzdeleri

\section{BULGULAR}

Çocuk acil tıp kliniğimize Eylül 2015-Eylül 2016 tarihleri arasında başvuran 39756 hastanın \%1.71'ini (n:683) adli vakaların oluşturduğu görüldü. Tüm hastaların yaş ortalaması 5,82 $\pm 4,75$ olarak bulundu. Erkek çocukların yaş ortalaması $6,37 \pm 5,16$ iken kız çocuklarınki 5,36 $\pm 4,32$ olarak tespit edildi. Yaş gruplarına göre değerlendirildiğinde en fazla başvurunun beș yaş altı grupta (n:434, \%63,5) olduğu tespit edildi (Tablo 1). Çocuk acile gelen adli olguların 316'sının kı $(\% 46,3)$ ve 367 'sinin erkek $(\% 53,7)$ olduğu tespit edildi.

Adli olayların cinsiyete göre dağılımı incelendiğinde (Tablo 2) 39 öz kıyım vakasının \%84,6'sının (n: 33) kız olduğu, 19 uyuşturucu kullanımı vakasının ise \%89,5'inin (n: 17) erkek olduğu görülmüştür. Öz kıyım kız çocuklarda, uyuşturucu kullanımı ise erkek çocuklarda istatistiksel olarak anlamlı düzeyde daha yüksek bulundu. (sırasıyla p<0,001$\mathrm{p}<0,001$ ).

Adli olayların dağılımı incelediğinde en fazla intoksikasyon vakalarının (n: 260, \%38,1) görüldügü tespit edildi (Şekil 1). İntoksikasyon vakaları kendi aralarında incelendiğinde en sık 
ilaç intoksikasyonu olgularının $(\% 43,6)$ (n: 140) olduğu tespit edildi. Bunu \%28,3 (n: 91) oranı ile korozif madde alımı ve \%21,5 (n: 69) oranı ile diğer kimyasallar izledi (Şekil 2). İlaç intoksikasyonu ile başvuran hastaların en sık \%25 (n:35) oranında non-steroid antiinflamatuar ilaç ile zehirlenmiş olduğu, bunu \%19,3 (n: 27) oranı ile antipsikotik, antidepresan ve antiepileptik ilaçların izlediği görüldü. Çocukların aldığı ilaçların büyük çoğunluğunun $(\% 81,4) \quad$ (n: 114) başka bir erişkinin ilacı olduğu görüldü. Korozif olarak kabul edilen maddeler ile olan 91 intoksikasyon olayının \% 49,5'inin (n: 45) çamaşır suyu ile olduğu tespit edildi.

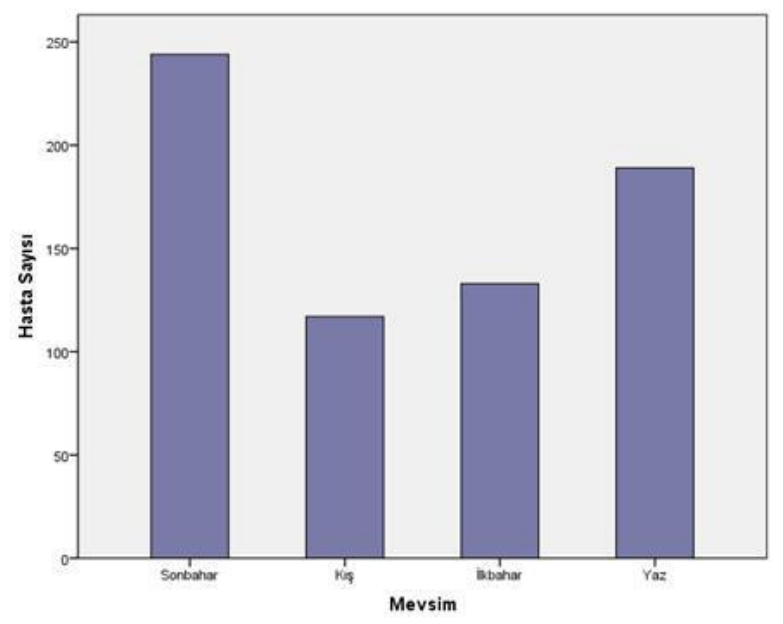

Şekil 3: Adli vakaların mevsimlere göre dağılımı

Olayların yaş gruplarına göre dağılımı incelendiğinde intoksikasyon vakalarının $\% 77,7$ sinin (n: 202), yabancl cisim yutma vakalarının \%62,3'ünün (n: 81) ve yabancı cisim aspirasyonu vakalarının \%90,5'inin (n: 19) 5 yaș altında, öz kıyım vakalarının \%76,9'unun (n: 30) ve uyuşturucu kullanımı vakalarının \%89,5'inin (n: 17) en sık 15 yaş üstünde görüldügü tespit edilmiştir. Öz kıyım nedeniyle başvuran toplam 39 vakanın \%97,4'ünün (n: 38) çeşitli ilaçlarla, yalnızca $\% 2,6$ 'sinın (n: 1) fare zehiri ile intihar girişiminde bulunduğu tespit edildi.

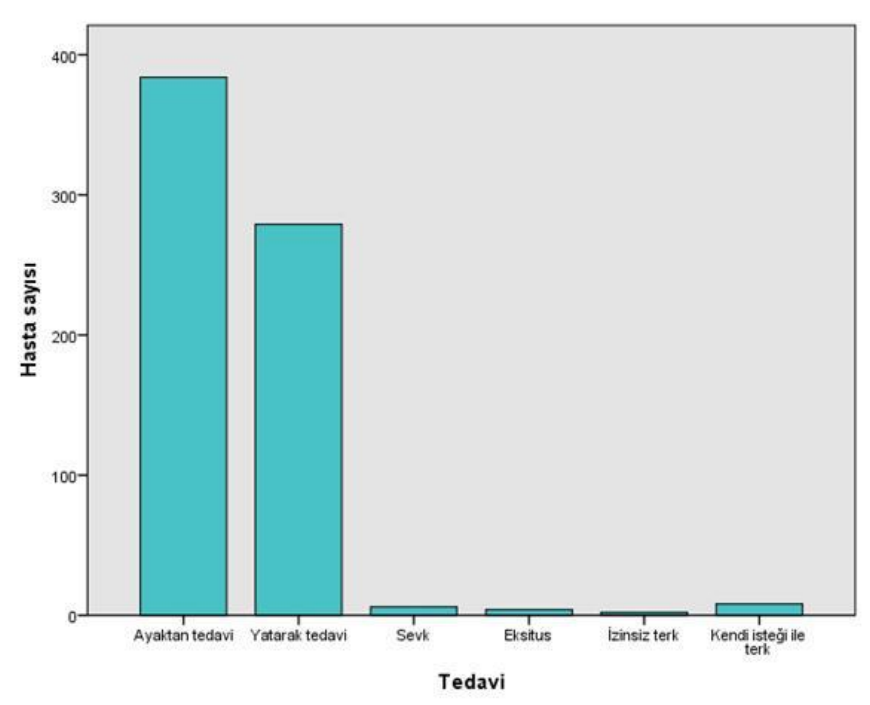

Şekil 4: Adli vakaların tedavi şekilleri

Vakaların çocuk acil servisine başvuru süreleri, olayın gerçekleşme zaman dilimi ve gerçekleştiği mevsim incelendiğinde \%42,6'sının (n: 291) ilk bir saat içinde, \%32,8'inin (n: 224) 1-3 saatte, \%18,7'sinin (n: 128) 4-10 saatte, \%3,4' ünün (n: 23) 11-20 saatte ve $\% 2,5^{\prime}$ inin ise (n: 17) 24 saatten daha uzun sürede hastaneye başvurduğu görüldü. Olayların gerçekleşme zaman dilimleri karşılaştırıldığında en sık \%44,5'inin (n: 304) akşam ve \%30,7'sinin (n: 210 ) öğle saatlerinde gerçekleștiği tespit edildi. Gerçekleştiği mevsimlere bakıldığında \%35,7'si (n: 244) sonbahar ve \%27,7'si (n: 189) yaz aylarında başvurmuştu (Şekil 3).

Çocuk acil servisine başvuran 683 hastanın \%56,2'sinin (n: 384) ayaktan, \%40,8'inin (n: 279) yatarak tedavi edildiği, \%1,2'sinin (n: 8) kendi isteği ile hastaneyi terk ettiği, \%0,9'unun (n:6) çeşitli nedenlerle sevk edildiği, \%0,6'sının (n:4) eksitus olduğu, \%0,3'ünün (n: 2) izinsiz olarak hastaneyi terk ettiği görüldü (Şekil 4).

Hastaların yalnız \%0,6'sının (n: 4) yoğun bakım ihtiyacı olduğu belirlendi. Aspirasyon ya da aspirasyon şüphesi ile başvuran hastaların en sık \%30,8'inin (n: 8) mama veya besin içeriği aspire ettiği, \%26,9'unun (n: 7) ise kuruyemiş aspire ettiği görüldü. Aspirasyon ya da 
aspirasyon şüphesi ile başvuran toplam 28 hastanın \%12,1'ine (n: 15) bronkoskopi uygulandığı tespit edildi.

Yabancı cisim yutma ya da yutma şüphesi ile başvuran hastaların en sık \%24,3'ünün (n:34) madeni para, \%16,4'ünün (n: 23) pil, \%14,3'ünün (n: 20) iğne yuttuğu saptandl. Yabancı cisim yutma ya da yutma şüphesi ile başvuran toplam 140 hastanın \%12,1'ine (n: 17) endoskopi uygulandığı belirlendi. .

Karbonmonoksit zehirlenme vakalarının (n:42) başvuru zamanı mevsimlere göre karşılaştırıldığında hastaların en sık $(\% 47,6)$ (n:20) sonbahar döneminde görüldüğü tespit edildi.

\section{TARTIŞMA}

Hem erişkin hem de çocuk acil servislerine müracaat eden hastalar arasında adli vaka niteliği taşıyanlar önemli yer tutmaktadır ${ }^{3}$. Sağlık kuruluşlarının acil servisleri adli vakaların başvurduğu ilk yetkili birimlerden biri olması sebebiyle, adli durumların saptanmasında önemli görevler üstlenmektedir. Bölgemizin çocukluk çağı adli vaka profilini belirlemek amacıyla çocuk acil servisimizin son bir yıllık adli vaka kayıtlarını inceledik. Bölgemiz için ilk olan bu çalışma, çocuklar için önlenebilir sağlık sorunlarının başında gelen adli olayların tanımlanması ve gerekli önlemlerin alınması için yapılacak çalışmalara ışık tutacaktır.

Ülkemizde yapılan farklı çalışmalarda acil servise başvuran adli vakalar içerisinde çocuk yaş grubu oranı \%18-31 arasında bildirilmiştir4-7. Bizim çalışmamızda bu oran $\% 70$ olarak oldukça yüksek tespit edildi. Bu durumun bölgemizde tam kapsamlı birçok erişkin acil servis olmasına karşın, çocuk acil servislerinin yetersiz olması ve bölgedeki hastaların büyük çoğunluğunun hastanemiz çocuk acil servisine yönlendirilmesine bağlı olduğu düșünüldü. Hastaların ortalama başvuru yaşının $5,82 \pm 4,75$ olduğu ve başvuru sıklığının
5 yaş altı grupta yüksek olduğu görüldü. Özdemir ve ark. adli olguların ortalama başvuru yaşlarını $8,77 \pm 4,99$ bulurken, Sever ve ark. 8,91 $\pm 5,08$ bulmuştur 8,9 . Çalışmamızda yaș ortalamasının daha düșük tespit edilme sebebi, travma hastalarının çalıșma dıșında bırakılmıș olmasına ve hasta popülasyonumuzun önemli bir kısmını oluşturan intoksikasyonların beş yaș altında daha sık görülmesine bağlandı.

Amerikan Hastalık Kontrol ve Önleme Merkezi (CDC) verilerine göre ölümcül olmayan yaralanmalar 1-19 yaș aralığında erkek çocuklarda kız çocuklarına göre daha fazla görülmektedir ${ }^{10}$. Ülkemizde ve yurtdışında yapılan çalışmalarda da erkeklerde kazara yaralanma ve adli vaka başvurularının kızlara göre daha fazla olduğu bildirilmekte, bu sebeple erkek cinsiyet varlığı bir risk faktörü olarak görülmektedir. $\mathrm{Bu}$ durum erkek çocukların daha aktif olması ve ilgi alanlarının farklılığ ile açıklanmaktadır ${ }^{4,5,9}$. Çalışmamızda ise istatistiksel olarak anlaml olmamakla birlikte adli vaka oranının erkek çocuklarda $(\% 53,7)$ daha fazla olduğu görüldü. Adli olayların cinsiyete göre dağılımı tek tek incelendiğinde öz kıyım vakalarını kız çocuklarında, uyuşturucu kullanımı vakalarının ise erkek çocuklarda anlamlı derecede daha sık olduğu görülmüştür (sırasıyla $\mathrm{p}<0.001-\mathrm{p}<$ 0.001). Çalışmalarda intihar girişimi vakalarında kız hasta oranı \%70 ile \%96 arasında bildirilmiştir. İntihar yöntemlerine bakıldığında kızların daha az ölümcül yöntemlere başvurduğu görülmüştür ${ }^{11,12}$. Ülkemizde yapılan çalışmalarda da literatürle uyumlu olarak kız hastaların daha fazla intihar girişiminde bulundukları saptanmıștır ${ }^{13}$ Ergenlik dönemi sonrası kızlarda duygu durum bozukluklarının daha yaygın görüldügü, kız çocuklarının daha duygusal ve kırılgan olması gibi çeşitli nedenler bu yaygınlığ açlklamaktadır.

Çalışmamızda intoksikasyon vakaları incelendiğinde \%77,7'sinin (n:202) beş yaș altında olduğu görülmüștür. Amerika Birleşik 
Devletleri'nin raporlarına göre zehirlenmelerin büyük kısmının beş yaşından küçük çocuklarda olduğu bildirilmiştir ${ }^{14}$. Ülkemizde yapılan hemen tüm çalışmalarda da zehirlenmelerin en sık 1-5 yaşları arasında görüldüğü bildirilmiştir ${ }^{15,16}$. Zehirlenmelerin beş yaş altında daha sık görülme nedeni, bu yaştaki çocukların sürekli çevre ile etkileşim ve keşfetme sürecinde olmaları sonucu çocukluk çağı kazaları açısından risk altında olmalarıdır ${ }^{17}$. Çalışmamızda intoksikasyon vakaları tüm yaşlarda \%60,8 oranı ile erkeklerde daha sık görüldü. Ülkemizde yapılmış diğer çalışmalarla benzer sonuçlar bulunmuştur ${ }^{18,19}$. Bu durum erkek çocukların kızlara göre daha hareketli, meraklı ve araștırmacı yapıda olmaları ve zehirli olanları olmayanlardan ayırt edebilme bilinç düzeyinde olmamaları ile açıklanabilir.

Çocuk acil servislerine intoksikasyon tanısıyla gelen adli vakaların en sık sebebi kazara ilaç içmeydi. Bunun yanında korozif madde alımı ve diğer kimyasal madde alımları da başvuruların büyük kısmını oluşturmaktaydı. Zehirlenmeler tüm dünyada olduğu gibi ülkemizde de özellikle çocukluk yaş grubunda sık görülen önemli bir sorundur. Olguların çoğunda etken madde ilaçlardır ${ }^{20,21}$. Bizim çalışmamızda da intoksikasyon olgularının en sik sebebi istatistiksel olarak anlaml olmamakla birilikte (p>0,05) \%36,2 ile (n: 94) kazara ilaç alımıydı. Yine istatistiksel olarak anlaml olmamakla birlikte ilaç alan çocuklar incelendiğinde ilaçların \%81,4'ünün başka bir erişkinin ilacı olduğu görüldü $(p>0,05)$. Korozif maddelerin alınması sonucu oluşan korozif hasar dünya çapında yaygın bir pediatrik acil sorundur ${ }^{22}$. Biz çalışmamızda intoksikasyon vakalarında ikinci sıklıkta \%33,8 (n: 88) oranında korozif madde alımı tespit ettik. Ülkemizde Çam ve arkadaşlarının ${ }^{23}$. yaptıkları çalışmada da bizim çalışmamıza benzer olarak korozif madde ile zehirlenme olgularının ilaç alımından sonra ikinci sıklıkta olduğu belirtilmiştir. Bu sonuçlar ailelerin devamlı kullandıkları ilaçları ve diğer zararlı maddeleri uygun koşullarda saklamasının ne kadar büyük önem arz ettiğini göstermektedir.

Çalışmamızda vakaların mevsimlere göre dağılımı incelendiğinde en fazla hastanın anlamlı oranda (\%35,7- p: 0,004) sonbahar döneminde başvurduğu, ikinci sıklıkla yaz $(\% 27,7)$ döneminde başvurduğu görülmüştür. Ülkemizde yapılan çeşitli çalışmalarda adli olayların daha çok yaz aylarında olduğu tespit edilmiştir 8,24 . Bizim çalışmamızda yaz döneminin ikinci sırada olmasını bölgemizdeki karbon monoksit zehirlenmesi oranının yüksek olması ve bu vakaların da sıklıkla sonbahar döneminde başvurmasına bağlandı. Hastaların gün içindeki başvuru zamanı incelendiğinde, önceki çalışmalar ${ }^{24,25}$. ile uyumlu olarak çalışmamızda da karbon monoksit intoksikasyonu dışındaki tüm vakaların başvuru oranlarının akşam ve öğlen saatlerinde anlamlı derecede yüksek olduğu (sırasıyla \%44,5- \%30,7- $\mathrm{p}<0.001$ ) görülmüștür. Bu sonucun, çocukların okul sonrası, ebeveyn gözetiminden uzak olarak, oyun ve sosyal aktivitelerini sıklıkla bu zaman diliminde gerçekleștirmeleri ile ilgili olduğu düşünüldü. Karbon monoksit zehirlenme vakalarının ise en sık gece sabaha karşı $(\% 35,7)$ ve sabah erken saatte $(\% 38,1)$ başvurduğu tespit edildi $(p>0,05)$. Mevsimlere göre incelendiğinde karbon monoksit zehirlenmelerinin en sık sonbahar ve kış döneminde görüldüğü tespit edildi. Arıcı ve arkadaşlarının yaptığı çalışmada da benzer olarak karbon monoksit zehirlenmeleri kış döneminde daha sık görülmüş ${ }^{26}$. Sonbahar ve kış dönemlerinde rüzgarların siddetli olması, karbon monoksit üreten ısınma araçlarının kullanımı, kișilerin gece boyu kapalı alanda kalması ve oksijen maruziyetinin azalması risk faktörlerini oluşturmaktadır.

Yabancı bir maddenin solunum yoluna kaçması neticesinde oluşan yabancı cisim aspirasyonları özellikle çocuk yaş grubunda ciddi sonuçlara neden olabilen önemli pediatrik aciller 
arasındadır. Her yaşta görülebilmesine karşın yabancı cisim aspirasyonlarının yapılan çalışmalarda en sık 1-3 yaş arasında görüldüğü bildirilmiştir ${ }^{27,28}$. Bizim çalışmamızda da istatistiksel anlamlı olarak beş yaş altı vakalarda $(\% 90,5)$ daha sık olduğu tespit edilmiş ( $\mathrm{p}<0.001)$ ve bu vakaların \%71,4'üne bronkoskopi yapıldığı tespit edilmiştir. Bronkoskopilerde çıkarılan yabancı cisimlerin \%38,1'i kuruyemiş, \%38,1'i çeşitli cisimler (oyuncak parçaları, iğne vb.), \%14,3'ü tanımlanamayan besin parçaları ve $\% 9,5^{\prime} \mathrm{i}$ şeker parçacıkları idi.

Yabancı maddelerin sindirim kanalına kaçması sonucu gelişen yabancı cisim yutma vakaları çocukluk çağında sıklıkla karşılaşılan problemlerden bir diğeridir ${ }^{29}$. Çalışmamızda yabancı cisim yutan vakaların \%62,3'ü istatistiksel anlamlı olarak ( $\mathrm{p}<0.001)$ beş yaşın altındaki çocuklardı. Literatürde oyun çağı çocuklarında daha sık karşılaşılan yabancı cisim yutan olgulara yaklaşım değişiklik göstermektedir5,6,9. Olgularımızın \% 86,9'unda yutulan yabancı cisim herhangi bir girişim gerektirmeden kendiliğinden vücuttan atılmıştır. Yutulan yabancı cismin türü ve gastrointestinal sistemdeki yerleşim yerine göre hastaya uygulanacak tedavi belirlenir. Yutulan cisimler incelendiğinde en çok madeni para $(\% 23,8)$, pil $(\% 16,9)$ ve iğne $(\% 13,8)$ yutulduğu tespit edilmiştir. Beş yaş altı grupta hem yabancı cisim yutma hem de yabancı cisim aspirasyon vakalarının bu kadar sık görülmesinin sebebinin, bu yaş grubu çocukların nesneleri ve yeni karşılaştıkları her şeyi tanımak için ağızlarını kullanma eğiliminde olmasına bağlanmıştır.

Tüm dünyada olduğu gibi ülkemizde de kazalar ve intoksikasyon vakaları, önlenebilir ölüm nedenlerinin başında gelmektedir. $\mathrm{Bu}$ tür olayların azaltılabilmesi ve yaralanma kontrolünün sağlanabilmesi için çocuklar için güvenli bir çevre oluşturulması önem arz etmektedir. Çocukların yaşadığı çevrelerde ve evde güvenlik için gerekli düzenlemeler yapılmalı, güvenliği sağlamak için gerektiğinde uygun güvenlik araçları kullanılmalıdır. Ayrıca eğitimciler ve sağlık profesyonelleri tarafindan çocuklara ve ebeveynlere yaralanma-korunma programları çerçevesinde düzenli eğitimler verilmelidir.

Çıkar Çatışması Beyanı: Yazarlar çıkar çatışması olmadığını bildirmişlerdir.

Finansal Destek: Bu çalıșma her hangi bir fon tarafından desteklenmemiştir.

Declaration of Conflicting Interests: The authors declare that they have no conflict of interest.

Financial Disclosure: No financial support was received.

\section{KAYNAKLAR}

1. Adli Tıp Uzmanları Derneği. Birinci Basamak İçin Adli Tıp El Kitabı. Polat Matbaası, Ankara. 1999:83-4.

2. Baysal S, Birinci A. Çocukluk çağında kazalar ve yaralanma kontrolü. Türkiye Klinikleri J Pediatr Sci. 2006;2:64-78.

3. Koç S, Çetin G, Kolusayın Ö. Acil olgularda hekimin sorumluluğu ve adli tıp sorunları. Sendrom. 1994;6:549.

4. Çınar O, Acar YA, Çevik E, et al. Acil servise başvuran 018 yaş grubu adli olguların özellikleri. Anatol J Clin Investig. 2010;4:148-51.

5. Büken E, Yaşar ZF. Başkent Üniversitesi Ankara Hastanesi Acil Servisine Başvuran Adli Nitelikteki Çocuk Olguların Değerlendirilmesi. Adli Tıp Bülteni. 2015;20:93-8.

6. Türkmen N, Akgöz S, Çoltu A, Ergin N. Uludağ Üniversitesi Tıp Fakültesi acil servisine başvuran adli olguların değerlendirilmesi. Uludağ Üniversitesi Tıp Fakültesi Dergisi. 2005;31:25-9.

7. Korkmaz T, Erkol Z, Kahramansoy N. Acil Servise Gelen Pediatrik Adli Olguların Değerlendirilmesi: Retrospektif Bir Çalışma. Med Bull Haseki. 2014;52:271-7.

8. Özdemir AA, Elgörmüş Y, Çağ Y. Acil Servise Gelen Adli Nitelikli Çocuk Olguların Değerlendirilmesi. Int J Basic Clin Med. 2016;4:1-8. 
9. Sever M, Ulaş E, Koşargelir M. Bir üçüncü basamak hastane acil servisine başvuran adli nitelikli çocuk hastaların değerlendirilmesi. Ulus Travma Acil Cerrahi Derg. 2010;16:260-7.

10. Borse N, Sleet DA. CDC Childhood Injury Report: Patterns of Unintentional Injuries Among 0-to 19-Year Olds in the United States, 2000-2006. Fam Community Health. 2009;32:189.

11. Garrido RR, García GJ, Carballo RE et al. Voluntary poisoning as a form of attempted suicide. An Esp Pediatr. 2000;53:213-6.

12. Jay MS, Graham CJ, Flowers C. Adolescent suicide attempters presenting to a pediatric facility. Adolescence. 1989;24:467-72.

13. Aktepe E, Kandil S, Goker Z, et al. İntihar girişiminde bulunan çocuk ve ergenlerde Sosyodemografik ve psikiyatrik özelliklerin Değerlendirilmesi. TAF Prev Med Bull. 2006;5:444-54.

14. Bronstein AC, Spyker DA, Cantilena Jr LR et al. 2006 Annual Report of the American Association of Poison Control Centers' National Poison Data System (NPDS). Clin Toxicol (Phila). 2007;45:815-917.

15. Genç G, Saraç A, Ertan Ü. Çocuk hastanesi acil servisine başvuran zehirlenme olgularının değerlendirilmesi. Nobel Med. 2007;3:18-22.

16. Ertekin V, Altinkaynak S, Alp H, Yigit H. Çocukluk çaginda zehirlenmeler. Son üç yıldaki vakaların değerlendirilmesi. Çocuk Dergisi. 2001;1:104-9.

17. Oguche S, Bukbuk D, Watila I. Pattern of hospital admissions of children with poisoning in the SudanoSahelian North eastern Nigeria. Niger J Clin Pract. 2007;10:111-5.

18. Kırel B, Ünlüoğlu İ, Doğruel N, Koçak K. Eskişehir bölgesinde çocukluk çağ retrospektif değerlendirmesi. Türkiye Klinikleri J Pediatr. 2000;9:158-63.

19. Bükülmez A, Tahta EG, Şen TA, Alpay F. Çocuk acil servisine başvuran zehirlenme vakalarının değerlendirilmesi. Kocatepe Tıp Dergisi. 2013;14:11-6.
20. Aygin D, Açıl H. Çocuk acil ünitesine başvuran 0-18 yaş arası zehirlenme olgularının incelenmesi. ŞEEAH Tıp Bülteni. 2014;48:27-33.

21. Özcan $T$, Tosun A, İnan G ve ark. Hastanemize başvuran zehirlenme olgularının değerlendirilmesi. ADÜ Tıp Fakültesi Dergisi. 2002;3:5-8.

22. Marshall F. Caustic burns of the esophagus: ten-year results of aggressive care. South Med J. 1979;72:12367.

23. Çam H, Kıray E, Taştan Y, Özkan HÇ. İstanbul Üniversitesi Cerrahpaşa Tıp Fakültesi Çocuk Sağlı̆̆ı ve Hastalıkları Anabilim Dalı Acil servisinde izlenen zehirlenme olguları Orijinal Araștırma. Turk Pediatri Ars. 2003;38:233-9.

24. Demir ÖF, Aydın K, Turan F et al. Acil Servise Başvuran Çocuk Adli Olguların Analizi. Turk Pediatri Ars. 2013;48: 235-40.

25. Korkmaz T, Kahramansoy N, Erkol Z, Sarıçil F, Kılıç A. Acil servise başvuran adli olguların ve düzenlenen adli raporların değerlendirilmesi. Med Bull Haseki. 2012;50:14-20.

26. Arıcı AA, Demir Ö, Özdemir D, Ünverir P, Tunçok Y. Acil servise başvuran karbonmonoksit maruz kalımları: On dört ylllı analiz. DEÜ Tıp Fakültesi Dergisi. 2010;24:25-32.

27. Lemberg PS, Darrow DH, Holinger LD. Aerodigestive tract foreign bodies in the older child and adolescent. Ann Otol Rhinol Laryngol. 996;105:267-71.

28. Carluccio F, Romeo R. Inhalation of foreign bodies: epidemiological data and clinical considerations in the light of a statistical review of 92 cases. Acta Otorhinolaryngol Ital. 1997;17:45-51.

29. Kefeli A, Başyiğit S, Yeniova Ö, Nazlıgül Y, Küçükazman M, Aktaş B. Üst gastrointestinal sistem yabancı cisimleri. Dicle Med J. 2014;41:195-8. 